динамических свойств конструкционных материалов, способной генерировать нагружающие импульсы в диапазоне от 1 до до 40 ГПа. Диапазон скоростей снаряда с ударником от 80 до 1620 м/с. Скорость ударника подбиралась таким образом, чтобы в процессе неупругого взаимодействия температура аморфной ленты не превышала $350{ }^{\circ} \mathrm{C}$.

Проведенные исследования методами рентгено-структурного анализа и атомной силовой микроскопии показали, что механическое ударное нагружение приводит к мгновенной нанокристаллизации фольги аморфного сплава. Время процесса образования порядка 10 - 5 с. Процесс ударного нагружения сопровождается кратковременном нагревом образцов до $350{ }^{\circ} \mathrm{C}$ (что на $150{ }^{\circ} \mathrm{C}$ ниже термического порога кристаллизации) и приводит к полной кристаллизации аморфного сплава (во всем объеме лент толщиной 25 мкм) с выделением кристаллов твердого раствора $\alpha-\mathrm{Fe}(\mathrm{Si})$, близкого по составу к $\mathrm{Fe}_{80} \mathrm{Si}_{20}$, стабильной фазы $\mathrm{Fe}_{3} \mathrm{Si}$ и метастабильных гексагональных фаз. Полученный результат является еще одним косвенным доказательством возможности посткаскадных динамических эффектов при ионной бомбардировке.

1. Овчинников В.В. и др., Известия Вузов. Физика, 59, 3-8 (2016).

2. Овчинников В.В., УФН, 178, 991-1001, (2008).

3. Овчинников В.В., Махинько Ф. Ф., Гущина Н. В., ФММ, 118, 158-166, (2017).

4. Романов И.Ю. и др., Известия Вузов. Физика, 60, 157-165 (2017).

\title{
MATHEMATICAL MODELING OF NONLINEAR GROWTH RATES OF CRYSTALS WITH ALLOWANCE FOR MEIRS KINETICS
}

\author{
Makoveeva E.V. ${ }^{1 *}$, Alexandrov D.V. ${ }^{1}$ \\ 1) Ural Federal University, Yekaterinburg, Russia \\ *E-mail: eugenya1m@gmail.com
}

The process of nucleation and growth of crystals in a metastable medium is studied theoretically in the presence of Meirs kinetics. The removal of crystals and their "diffusion" in the space of radii are taken into account in the Fokker-Planck equation for the distribution function. The time-dependent external heat (or mass) flux which controls the level of system metastability is included in the heat (mass) balance equation. The effect of nonlinear growth rate for spherical crystals is shown.

The present work is concerned with a mathematical description of the phase transition process in a crystallizer when the kinetic equation takes into account the crystal withdrawal rate and the balance equation contain the heat (mass) source term. The distribution function $f$ accounting for the particle fluctuations and crystal withdrawal rate takes the form $[1,2]$

$$
\frac{\partial f}{\partial \tau}+\frac{\partial}{\partial r}(g f)+h(r) f=\frac{\partial}{\partial r}\left(D \frac{\partial f}{\partial r}\right), \quad r>r_{*} .
$$


Here $r$ and $\tau$ are the spatial and time variables, function $h(r)$ describes the crystal withdrawal rate and $r_{*}$ is the critical radius of crystals. The exact form of coefficient $D$ is a hard task of statistical physics. However, for the sake of simplicity, one can use the following approximation [1]

$$
D=d_{1} g(\tau, r)
$$

where $d_{1}$ is a constant coefficient. The growth rate $g$ of particles for the kinetic regime can be expressed as [3]

$$
g(\tau)=g(\Delta C)=\beta_{*} \Delta C(1-k \tau \Delta C), k=\frac{\beta_{*} \rho_{s} L}{\lambda_{l}},
$$

where $\Delta C$ (or $\Delta \Theta$ ) are the supersaturation (or supercooling), $C$ (or $\Theta$ ) are the current concentration of impurity (or temperature), $\beta_{*}$ is kinetic coefficient, $\lambda_{l}$ is the thermal conductivity, $\rho_{s}$ is the density of the solid phase, $L$ is the latent heat of phase transition. Let us assume that the coefficient $h$ is constant

$$
h=\frac{q}{V}, \quad 0 \leq r \leq r_{p}
$$

where $q$ and $V$ are the feed rate and total volume, $r_{p}$ is the radius of product crystals. Taking into account expressions (3)-(5) we rewrite the kinetic equation (1) in the form

$$
\frac{\partial f}{\partial \tau}+G(C) \frac{\partial f}{\partial r}+h f=d_{1} G(C) \frac{\partial^{2} f}{\partial r^{2}}
$$

The mass (heat) balance equations can be written as

$$
\begin{gathered}
\frac{d C}{d \tau}=Q_{C}-4 \pi C_{p} \int_{r_{*}}^{\infty} r^{2}\left(f(r, \tau) \frac{d r}{d \tau}-D \frac{\partial f}{\partial r}\right) d r \\
\rho_{m} C_{m} \frac{d \Theta}{d \tau}=Q_{\Theta}+4 \pi L_{V} \int_{r_{*}}^{\infty} r^{2}\left(f(r, \tau) \frac{d r}{d \tau}-D \frac{\partial f}{\partial r}\right) d r
\end{gathered}
$$

where $L_{V}$ is the latent heat of solidification, $C_{p}$ is the concentration at saturation, $\rho_{m}$ and $C_{m}$ are the density and heat capacity, $Q_{C}$ and $Q_{\Theta}$ are the external mass and heat fluxes.

We assume that the initial distribution function and supersaturation are known

$$
f=f_{0}(r), \tau=0 ; \Delta C=\Delta C_{0}, \tau=0 .
$$

The boundary conditions for the distribution function take the form [3]

$$
\begin{gathered}
g f-D \frac{\partial f}{\partial r}=I(\Delta C), \quad r=r_{*}, \quad \tau>0 \\
f=0, \quad r=r_{p}
\end{gathered}
$$

Fig. 1 shows that the nonlinear growth rate of particles in a metastable liquid of crystallizer substantially changes the particle size distribution. Parameter $\gamma$ characterizes the crystal withdrawal rate. 
ФТИ-2019

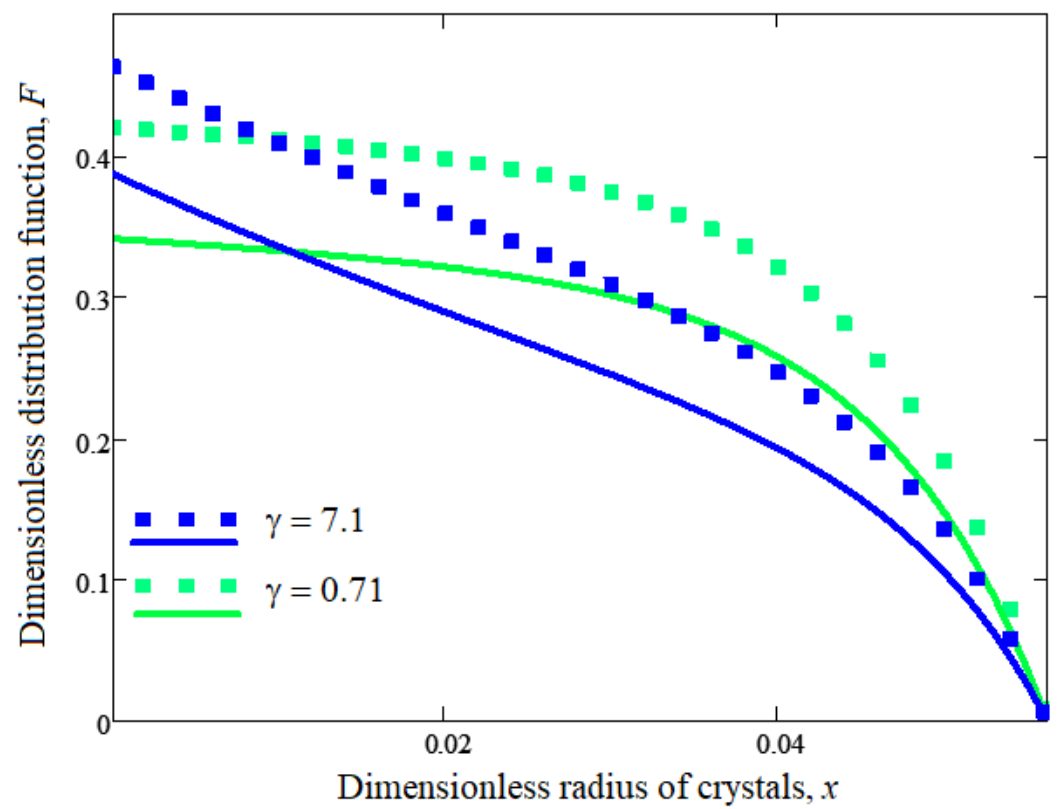

Fig. 1. Dimensionless distribution function versus dimensionless radius of crystals for $\mathrm{k}=0$ (straight line) and $k=2 \cdot 10^{-6}$ (dotted line).

1. Lifshitz E.M., Pitaevskii L.P., Physical Kinetics, Pergamon (1981).

2. Alexandrov D.V., Chem. Eng. Sci., 117, 156 (2014).

3. Alexandrov D.V., Malygin A.P., J. Phys. A: Math. Theor., 46, 455101 (2013).

\section{РАССЕЯНИЕ УЛЬТРАКОРОТКИХ ИМПУЛЬСОВ ЭЛЕКТРОМАГНИТНОГО ПОЛЯ ГРАФЕНОМ}

$$
\text { Макарова К.А. }{ }^{1 *} \text {, Есеев М.К. }{ }^{1} \text {, Макаров Д.Н. }{ }^{1}
$$

${ }^{1)}$ Северный (Арктический)федеральный университет им М.В. Ломоносова, Архангельск, Россия

*E-mail: ksenya931408@yandex.ru

\section{SCATTERING OF ULTRASHORT ELECTROMAGNETIC FIELD PULSES BY GRAPHENE}

Makarova K.A. ${ }^{1 *}$, Eseev M.K. ${ }^{1}$, Makarov D.N. ${ }^{1}$

${ }^{1)}$ Northern (Arctic) Federal University named after MV Lomonosov, Arkhangelsk, Russia

Annotation. The interference spectra are found for scattering of attosecond pulses of an electromagnetic field by graphene. Analytical expressions for the scattering spectra are obtained. It is shown that the interference spectra depend on defects in graphene.

Различные кристаллы и наноструктурированные мишени являются естественными дифракционными решетками для рентгеновского излучения. Обычно явление дифракции рентгеновских лучей на различные рода периодических 